\title{
What does vanishing bone disease look like?
}

\author{
Jarrad Stevens, ${ }^{1}$ Hannah Flower, ${ }^{2}$ James T Patton ${ }^{1}$
}

'Orthopaedic, Royal Infirmary of Edinburgh, Edinburgh, UK ${ }^{2}$ College of Medicine and Veterinary Medicine, University of Edinburgh, Edinburgh, UK

\section{Correspondence to}

Dr Jarrad Stevens,

drjarradstevens@hotmail.com

Accepted 10 March 2018

\section{DESCRIPTION}

A previously healthy 44-year-old female presented with an acute history of increasing pain and reduced range of movement in her left shoulder. MRI scan revealed an infiltrative lesion in the proximal humerus, with a degree of cortical thinning and soft tissue involvement; however, initial biopsy provided no definitive diagnosis. Due to the suspicion of underlying malignancy, additional biopsies were organised. A second biopsy provided no diagnosis; however, a third biopsy taken 2 months after presentation revealed a benign vascular lesion with callus formation. This was consistent with the suspicion of our radiologist that a pathological fracture of the proximal humerus had been sustained following a minor fall (figure 1).

Twelve months after presentation, with continued pain and swelling in the arm, further investigations were carried out. Radiographs demonstrated a second pathological fracture of the left proximal humerus, with intramedullary and subcortical radiolucent foci (figure 2). Contrast MRI scans and angiogram showed a more extensive vascular lesion than previously seen with no sign of arteriovenous malformation. Bone biopsy showed a highly vascular lesion with lymphovascular exudate and no obvious solid lesional tissue. Bone and soft tissue samples showed prominent osteoclastic bone resorption (figure 3). CT chest, abdomen and pelvis revealed no sign of malignancy. At that point, bone

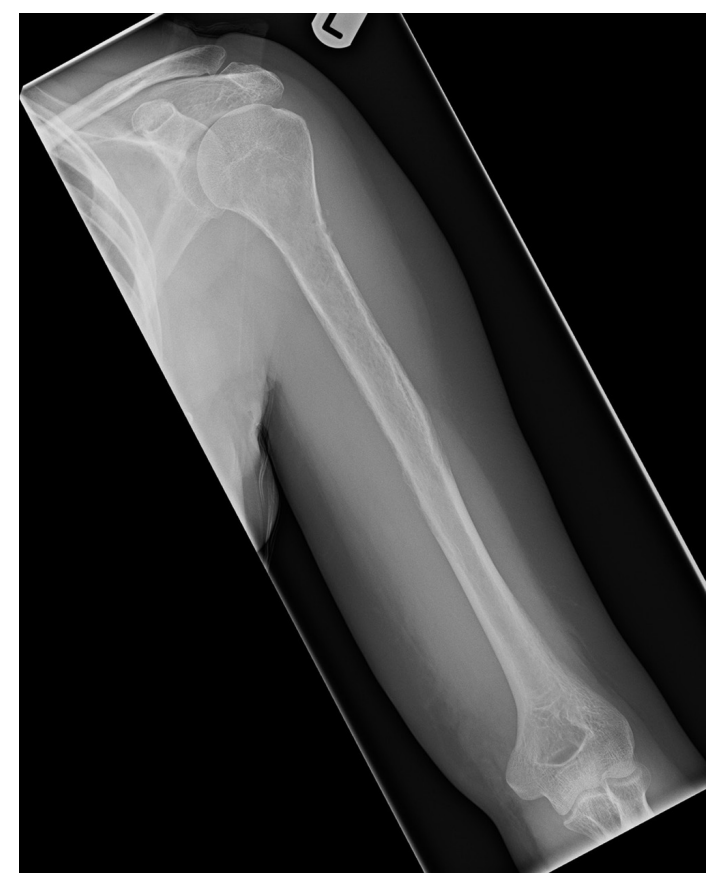

Figure 1 Radiograph of left humerus and shoulder at presentation.

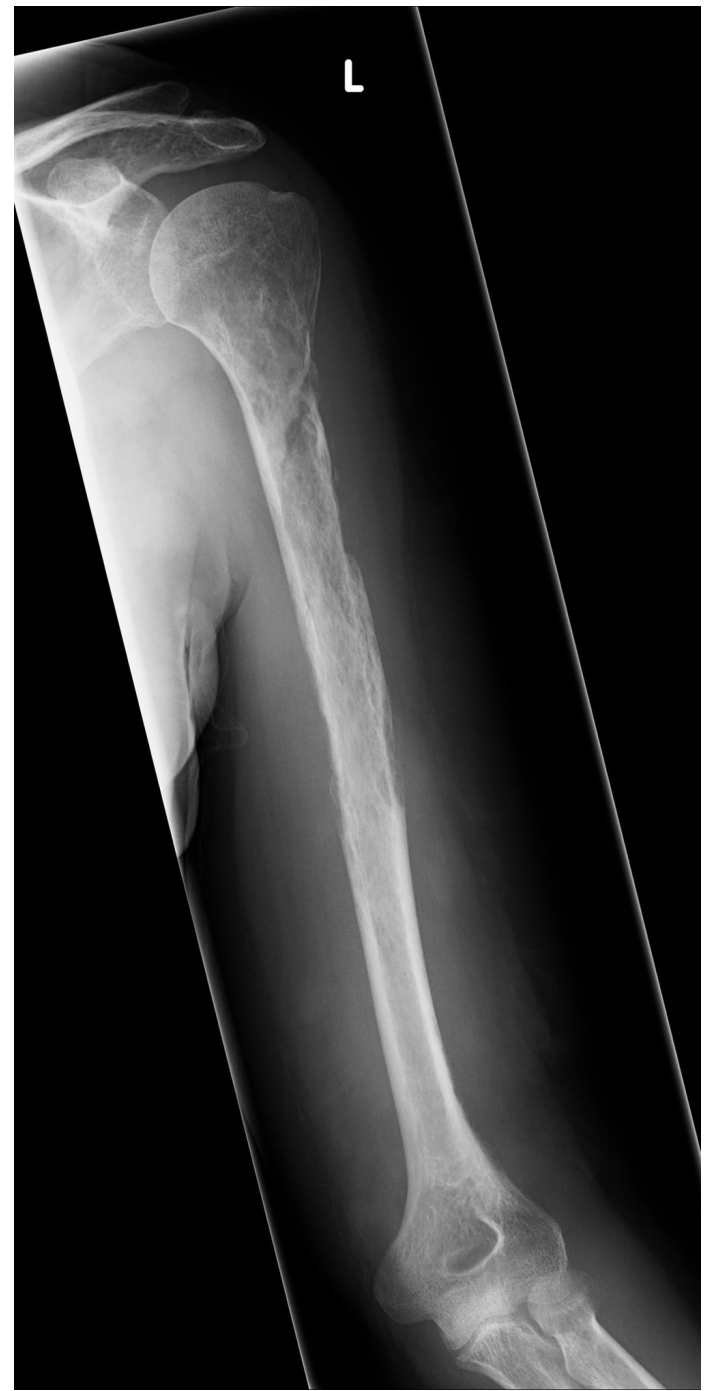

Figure 2 Radiograph of left humerus 12 months after initial presentation.

scan demonstrated isolated humerus involvement. However, subsequent radiographs taken 1 month later revealed rapidly spreading disease, with near-complete resorption of the humerus, and suspicion of disease spread to the ulnar (figure 4). At this point, with the histological and radiological findings, a diagnosis of Gorham-Stout disease (GSD) was considered, with a second opinion sought from the multidisciplinary team in Birmingham. A consensus diagnosis of rapid and multifocal GSD was made. The most recent X-ray is seen in figure 5 .

GSD or 'vanishing bone' disease is a rare disorder, characterised by the destruction of osseous matrix due to aggressive proliferation of non-neoplastic vascular and lymphatic tissue, similar to a haemangioma or lymphangioma. ${ }^{1}$ Only 64 cases have been 


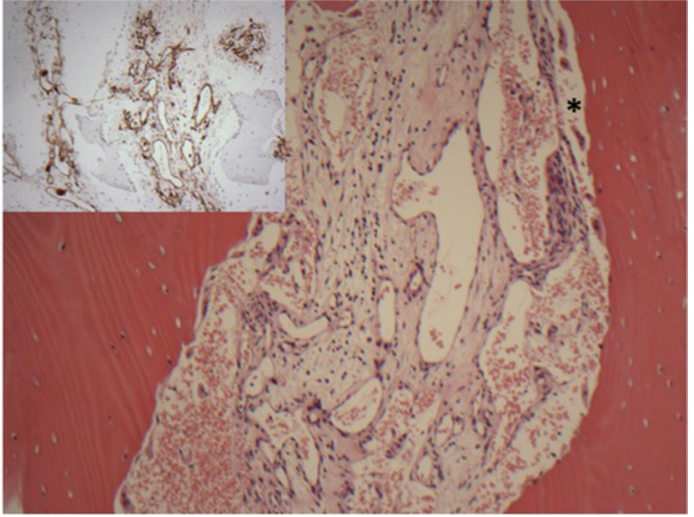

Figure 3 Biopsy of bone shows the marrow space to be replaced by thin-walled vessels of varying calibre. There is prominent osteoclastic bone resorption. ${ }^{*}$ Main panel: H\&E stain, original magnification $\times 10$. Inset: CD31 immunohistochemistry, original magnification $\times 10$.

reported in the literature, 8 of which have involved the humerus. While the condition is considered benign, the prognosis is uncertain, with potential fatal complications that include disease spread to the vertebrae, leading to pleural effusion and quadriplegia. The progressive bone loss can lead to complete bone resorption. Associations have been proposed between massive

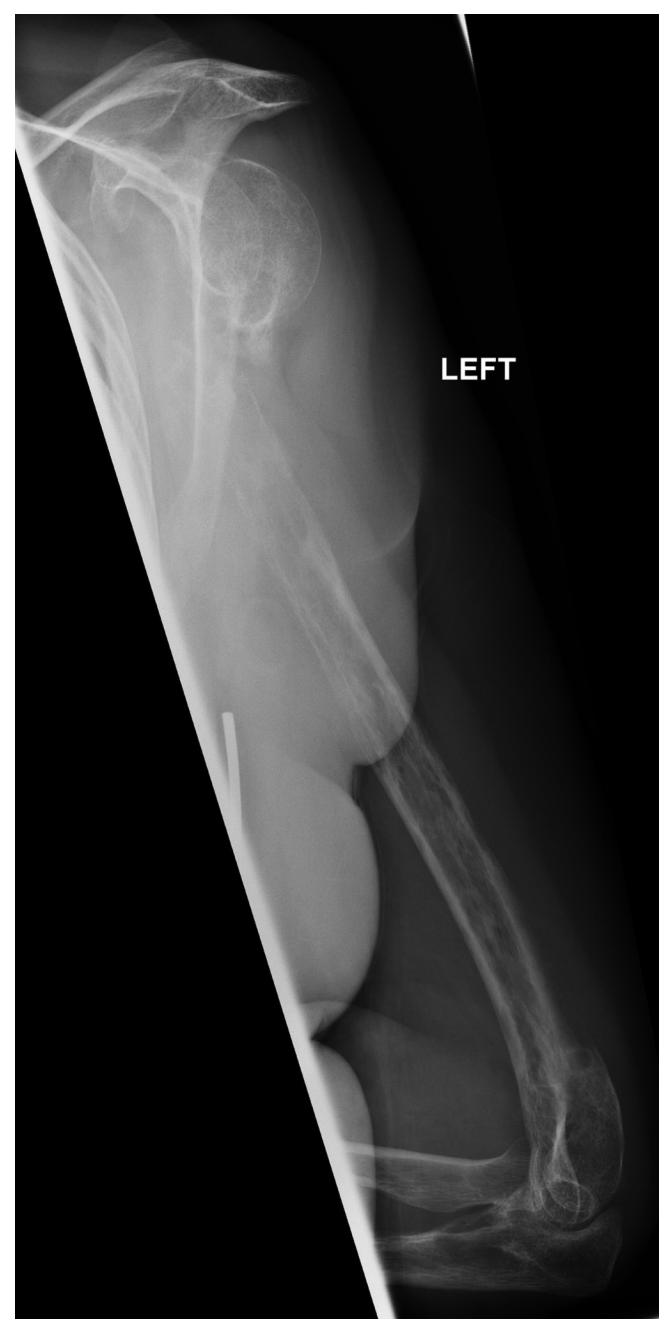

Figure 4 Radiograph of left humerus and elbow 15 months after presentation. Rapidly progressing and multifocal Gorham-Stout disease.

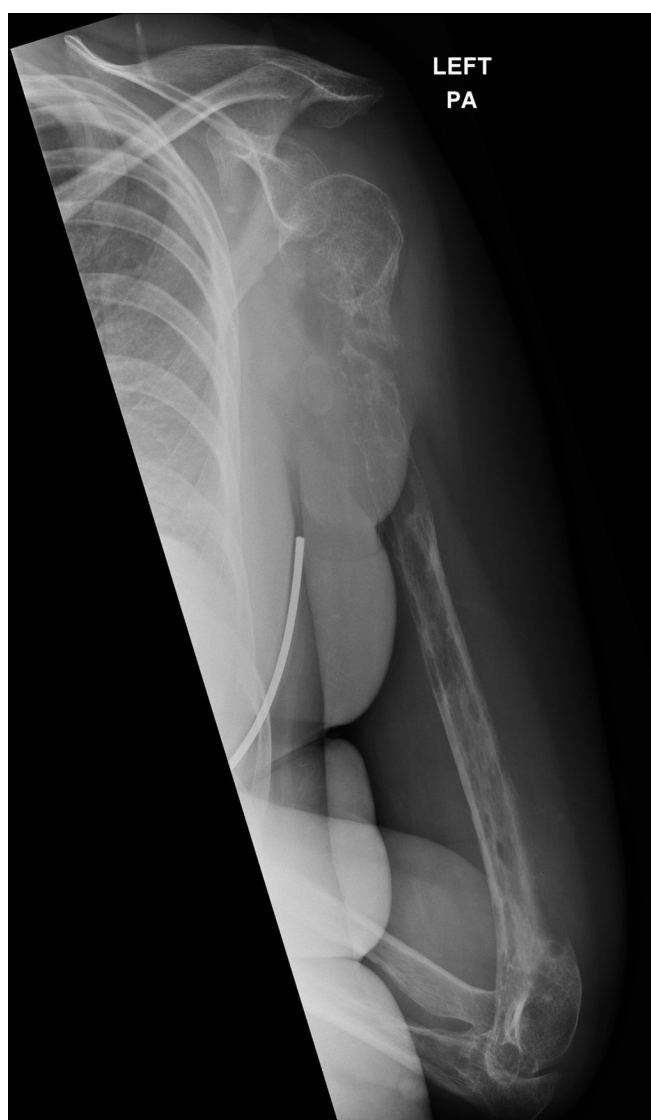

Figure 5 Radiograph of left humerus 18 months after presentation. PA, posterioranterior.

osteolysis following trauma or as a result of increased osteoclast and interleukin 6 activity. In spite of this, the definitive aetiology and pathology of the disease remain unknown. Due to its rarity, diagnosis is challenging and first requires the exclusion of more common disorders including neoplastic, inflammatory, infectious and endocrine disease. Presentation can include pain, functional impairment and swelling, although asymptomatic cases have been described. X-ray may show atrophy, bone tapering and pathological fractures. The gold standard for diagnosis is a biopsy demonstrating angiomatous tissue. ${ }^{2}$ This is an integral component of the diagnostic criteria for GSD proposed by Heffeze $e t a l^{3}$ :

- minimal/no osteoblastic response and absence of dystrophic calcification

- positive biopsy for angiomatous tissue

- absence of cellular atypia

- evidence of local progressive osseous resorption

- non-expansile, non-ulcerative lesion

- absence of visceral involvement

- osteolytic radiographic pattern

- negative hereditary, metabolic, neoplastic, immunological or infectious aetiology.

Treatment options remain limited and have varying success; some positive reports have been made after the use of multimodal therapy (radiation therapy, bisphosphonates and surgical resection). Ultimately, this is a challenging disease where evidencebased management remains lacking.

Contributors All authors contributed to the paper. JS and HF contributed to the literature review, case report write-up and draft manuscript. JTP conceived the the 


\section{Learning points}

- Gorham-Stout disease is an exceptionally rare, poorly understood and potentially fatal skeletal condition.

- Diagnosis requires a high degree of clinical suspicion, sometimes necessitating multiple images and biopsies.

- Treatments remain limited, and more evidence is needed to identify successful management strategies.

notion that this rare disease would be of importance to other surgeons, edited and checked the manuscript and references.

Funding This research received no specific grant from any funding agency in the public, commercial or not-for-profit sectors.
Competing interests None declared.

Patient consent Obtained.

Provenance and peer review Not commissioned; externally peer reviewed.

(c) BMJ Publishing Group Ltd (unless otherwise stated in the text of the article) 2018. All rights reserved. No commercial use is permitted unless otherwise expressly granted.

\section{REFERENCES}

1 Nikolaou VS, Chytas D, Korres D, et al. Vanishing bone disease (Gorham-Stout syndrome): A review of a rare entity. World J Orthop 2014;5:694.

2 Heffez L, Doku HC, Carter BL, et al. Perspectives on massive osteolysis. Report of a case and review of the literature. Oral Surg Oral Med Oral Pathol 1983;55:331-43.

3 Ruggieri P, Mavrogenis AF, Guerra G, et al. Preliminary results after reconstruction of bony defects of the proximal humerus with an allograft-resurfacing composite. I Bone Joint Surg Br 2011;93:1098-103.

Copyright 2018 BMJ Publishing Group. All rights reserved. For permission to reuse any of this content visit

http://group.bmj.com/group/rights-licensing/permissions.

BMJ Case Report Fellows may re-use this article for personal use and teaching without any further permission.

Become a Fellow of BMJ Case Reports today and you can:

- Submit as many cases as you like

- Enjoy fast sympathetic peer review and rapid publication of accepted articles

- Access all the published articles

Re-use any of the published material for personal use and teaching without further permission

For information on Institutional Fellowships contact consortiasales@bmjgroup.com

Visit casereports.bmj.com for more articles like this and to become a Fellow 